\title{
The Influence of Online Non-monetary Service Recovery on Firm Performance: Based on Online Reviews
}

\author{
Jinhong Cui ${ }^{1}{ }^{*}$, Xiaoying $\mathrm{Li}^{1}$, and Xu Wang ${ }^{2}$ \\ ${ }^{1}$ School of IT \& Management, University of International Business and Economics, Beijing, China \\ ${ }^{2}$ IBM, Beijing, China \\ cjh1616@126.com,1559287262@qq.com,wx1971@hotmail.com
}

Keywords: Service Recovery, Online Reviews, Firm Performance, Perceived Fairness

\begin{abstract}
Online reviews is a significant form of online service where firms show their corporate image and service quality, in the case of online information asymmetry. This research investigates the effectiveness of online non-monetary service recovery effort on firm performance improvement using data retrieved from a major online travel agency in China. Using the independently developed network data crawler system based on HttpClient crawler assembly to capture the hotel information and customer reviews information and other related data of Ctrip, this study applies Stata model regression to analyze the panel data and test model assumptions. Findings suggest that the firm's responses to online customer complaints as the representative of the non-monetary service recovery has a significant effect on promoting firm sales.
\end{abstract}

\section{Introduction}

User Generated Content, including online reviews, is a significant form of online service where firms show their corporate image and service quality in the case of online information asymmetry. Customers provide useful information of the service on online feedback platforms which also provides a close communication channel for online service firms. Service recovery refers to the actions a firm takes in response to a service failure (Gronroos, 1988). When service failure occurs, customers post complains and reviews online and the growing online feedback platforms presents new opportunities and challenges for firm service recovery (Priyanga, 2014; Huang, 2015). Service failure can reduce customers' satisfaction to the firm, but effective service recovery has become an important way to solve the problem.

Based on online reviews, this study measures the impact of online non-monetary service recovery on firm performance. This research analyzes related studies of online reviews, service recovery, firm performance and perceived fairness theory. Based on Java, using the independently developed network data crawler system based on HttpClient crawler assembly to capture the hotel information, customer reviews information, and other related data of Ctrip, this study apply Stata model regression to analyze panel data and test model assumptions. Findings suggest that responses to online customer reviews as the representative of the non-monetary service recovery has a significant effect on promoting firm sales. The timeliness and content length of online service 
recovery have positive effect on the firm sales significantly, and the greater difference of the rating score which customers give has positive role in promoting the firm sales.

The rest of the paper is organized as following. In Section 2, this research provides literature review on online reviews and service recovery. Section 3 describe the theoretical foundation and hypotheses. The data, econometric model and empirical results are presented in Section 4. In Section 5, conclusion is given based on the above results.

\section{Literature Review}

\subsection{Online Reviews}

The development of information technology has changed the environment significantly in which more and more customers spread information about products or services through online customer opinion platforms (Cheung, 2012; Yang, 2012; Wael, 2014). Prior studies found that online reviews have significant impacts on product or service sales (Chevalier, 2006; Cui, 2012; Li, 2014). Altruism, product involvement, and self enhancement have significant positive influence on the intention to spread customer reviews on online feedback system (Cui, 2014). Based on the social capital theory and social network theory, researchers considered how social capital of reviewers which includes a reviewer's social network, indegree and outdegree, experience, and activity affects the quality of review and even future customers (Li, 2015). Some researchers found emotions within review content significantly influence review helpfulness using real-world data and econometric model (Yin, 2014).

\subsection{Service Recovery and Firm Performance}

Service recovery is a way that a firm takes to cope with service failures to retain its customers and minimize the costs associated with customer defection and negative word of mouth (Boshoff, 1997). Since service failure cannot be avoided, service recovery is important for a firm to maintain customer satisfaction and firm performance. Firms need investigate how service recovery efforts influence the level of customer dissatisfaction and intention to complain when a service failure occurs (Maxham, 2001). Studies have shown that consumers' satisfaction and intention to complain are influenced by cause of failure, and perceived distributive and interactional justice in the service recovery effort, and customer satisfaction levels are higher after service recovery efforts following a service failure than in situations where no service failure occurs (Hocutt, 1997). Online management responses are highly effective among low satisfaction customers but have limited influence on high satisfaction customers and increase future satisfaction of the complaining customers who receive the responses but decrease future satisfaction of complaining customers who observe but do not receive management responses (Ye, 2014).

The length of negative reviews tends to increase after hotels begin responding, and management responses increase hotel ratings and total review volume for responding hotels (Proserpio, 2017). Researchers investigated the inflence of two online service recovery strategies which includes online information and technology-mediated communication on customer satisfaction, switching and word-of-mouth intentions, and found that interactional justice delivered through technologymediated communication was a strong predictor of satisfaction with online service recovery (Singh, 2016). Perceived justice and customers' emotions have direct or indirect influence on customers' satisfaction with service recovery, customer trust, and repurchase intentions (Wen, 2013). Prior studies suggested that successful service recovery can increase profits (Swanson, 2011). Researchers found that firms offering compensation or process improvement result in more stable 
performance, but firms that offer apology-based recovery show more volatile performance (Rasoulian, 2017).

Prior studies mostly focus on the impact of online service recovery on customer satisfaction and perceived justice (Steven, 2015), but the influence on firm performance need more study.

\section{Theory and Hypotheses Development}

\subsection{Perceived Fairness Theory}

Perceived fairness theory originated from social exchange and fairness theory. The three dimensions of perceived justice that influence how people evaluate exchanges include distributive justice, procedural justice and interactional justice. Distributive justice refers to resource allocation and the perceived outcome of exchange, procedural justice refers to the means by which decisions are made and conflicts are resolved, interactional justice refers to the manner in which information is exchanged and outcomes are communicated (Smith, 1999). Researchers suggested that procedural justice can be evaluated by the manner in which firms or firm representatives bear the responsibility of service failures, the speed in which complaints are addressed, and the speed in which the service problem is resolved (Wen, 2013). Studies found that service failures themselves do not necessarily lead to customer dissatisfaction, since most consumers accept that things can sometimes go wrong, but the organization's response or lack of response to service failures is the most likely cause of dissatisfaction (Río-Lanza, 2013).

\subsection{Hypotheses Development}

This research plans to investigate the impact of online non-monetary service recovery on firm performance. Based on perceived fairness theory, the three justice dimensions of perceived justice could impact on the customer satisfaction and firm performance. Since distributive justice focus on justice of resource allocation outcome and this study mainly discuss online non-monetary, distributive justice is not considered. For firm performance, this research measure it from customer perceived quality and firm sales.

Studies have shown that customer online reviews as a new complaint channel are able to influence thousands of purchase decisions and must be considered by marketers (Pinto, 2011; Mangold, 2012). Service failure can result in customer complaints, so it is essential that organizations take service recovery strategies to resolve the issue. Researchers have investigated the impact of service recovery and found that moderate levels of service recovery yield satisfaction scores that could be described as adequate (Boshoff, 2012). Gu and Ye analyzed the effectiveness of online service recovery effort on customer satisfaction using data retrieved from an online travel agency in China and found that online service recovery was highly effective among the least satisfied customers but had limited influence on other customers ( $\mathrm{Gu}, 2010)$. This research proposes:

Hypothesis 1a: Non-monetary online service recovery has positive effect on firm performance. In other words, hotels that take non-monetary online service recovery are able to get more online room booking than ones that do not take non-monetary service recovery.

Hypothesis 1b: Non-monetary online service recovery has positive effect on customer perceived quality. In other words, hotels that take non-monetary online service recovery are able to result in higher customer perceived quality than ones that do not take non-monetary service recovery.

Perceived fairness theory provides a clear and reasonable analysis framework, this research mainly analyzes two dimensions of perceived fairness theory: procedural justice and interactional justice. Procedural justice implies the methods organizations uses to deal with the problems arising during service delivery in accessibility, timing/speed, process control, delay and flexibility to adapt 
to the consumer's recovery needs (Río-Lanza, 2013; Wirtz, 2010). Studies show that both compensation and a speedy response have a greater incremental impact on customers' justice evaluations when the failure is less severe (Smith, 1999). This research proposes:

Hypothesis 2: The speed of non-monetary online service recovery positively affects firm sales. In other words, more quickly a hotel takes non-monetary online service recovery, higher the online room booking.

Interactional justice includes customers' perceptions about employees' attitude, courtesy and the effort they expend to solve the problem in service recovery. Studies have shown that review lengths have positive and statistically significant at Amazon.com and this implies that the length of the review is correlated with the enthusiasm of the review (Chevalier, 2006). The non-monetary online service recovery is a kind of online reviews, this conclusion is included into this study. Online employee' response indicate they do more effort to improve customer satisfaction and have positive effect on firm sales. This study proposes:

Hypothesis 3: The length of content of non-monetary online response positively affects firm sales. In other words, longer the content of non-monetary online response, higher the hotel online booking sales.

\section{Methodology}

\subsection{Data}

The data is collected from Ctrip.com which is the largest online travel agency in China. Ctrip.com provide a platform for customers to post online reviews for their hotel stays and the hotel employee to give managerial response to online customer reviews. Based on the Java, this study uses the independent development of the network data crawler system based onHttpClient crawler assembly to capture the hotel information and customer reviews information and other related data of Ctrip.

Two kinds of data are collected. One is basic information of a hotel which include city, hotel id, hotel name, hotel star, lowest price. The other is online customer reviews and hotel response to online reviews which include posting date of online customer reviews, review ratings, get hotel response or not and hotel response content. This study collect 1900 hotels information. In the end 1698 hotel information are useful in which 1675 hotels provide response to online reviews. There are 3262574 online reviews in which 1700559 reviews get hotel response from February 2013 to February 2016.

\subsection{Econometric Model}

This study uses a panel data of online customer reviews and online non-monetary service recovery effort in the form of online employee' responses at Ctrip.com. First this study tests the hypothesis of online employee' response impact on hotel performance. Online room booking sales is not shown on online travel platform in China. Since Ctrip only allows customers to post reviews after checking out, this study can use the number of online reviews for hotel instead of the hotel room sales (Ye, 2009). The models are established as follows:

$$
\begin{aligned}
& \ln \left(\text { Num_review }_{i t}\right) \\
& \quad=\mu+v_{i}+\beta_{1} \text { resp_dummy }_{i t}+\beta_{2} \text { resp_num }_{i t}+\beta_{3} \text { var_review }_{i t} \\
& \quad+\beta_{4} \ln \left(\text { price }_{i}\right)+\beta_{5} \text { hotel_class }_{i}+X_{i t} \Gamma+\varepsilon_{i t}
\end{aligned}
$$




$$
\begin{aligned}
\text { avg_review }_{i t} & =\mu+v_{i}+\beta_{1} \text { resp_dummy }_{i t}+\beta_{2} \text { resp }_{-} \text {num }_{i t}+\beta_{3} \text { var_review }_{i t} \\
& +\beta_{4} \ln \left(\text { price }_{i}\right)+\beta_{5} \text { hotel_class }_{i}+X_{i t} \Gamma+\varepsilon_{i t}
\end{aligned}
$$

In the above model (1) and (2), $u$ and $v_{i}$ represent fixed effect produced by Ctrip and hotel $\mathrm{i}$ heterogeneous condition. resp_dummy $y_{i t}$ represents whether hotel i take service recovery at time $t$, if it takes response, its value is 1 , otherwise 0. resp_num $i t$ represents number of response information hotel i take service recovery at time t. $X_{i t} \Gamma$ represents variables that can't be observed in change of hotel i at time t. Hotel_quality $i t$ is represented by avg_review $w_{i t}$ which is average customer rating of reviews of hotel $\mathrm{i}$ at time t. var_review ${ }_{i t}$ represents the variance of rating among reviews of hotel i at time t. hotel_class h $_{i}$ represents star class evaluated by the country. price $_{i}$ represents the lowest price of room in hotel i.

Then this study tests the influence of the speed of non-monetary online service recovery and the length of review content on hotel sales. The models are establish as follows:

$$
\begin{aligned}
& \ln \left(\text { Num_review }_{i t}\right) \\
& \quad=\mu+v_{i}+\beta_{1} \text { resp }_{-} \text {speed }_{i t}+\beta_{2} \text { resp_num }_{i t}+\beta_{3} \text { var_review }_{i t} \\
& \quad+\beta_{4} \ln \left(\text { price }_{i}\right)+\beta_{5} \text { hotel_class }_{i}+X_{i t} \Gamma+\varepsilon_{i t}
\end{aligned}
$$

In the above model (3) and (4),resp_speed ${ }_{i t}$ and resp_length $h_{i t}$ represent the speed of nonmonetary online service recovery and the length of review content respectively. According to prior studies, hotel response to online customer review in a month can be considered as response quickly. In this study, resp_dummy $i t$ represents whether hotel i take service recovery at time $\mathrm{t}$, if it takes response, its value is 1 , otherwise 0 . Forresp_length $h_{i t}$, since it is measured by length of hotel response and its value change greatly than other variables, this study uses $\ln \left(\right.$ resp_length $\left._{i t}\right)$ instead.

\subsection{Empirical Analysis}

After data pre-processing, Figure 1 provides a summary description of the data. 


\begin{tabular}{|c|c|c|c|c|c|}
\hline Vari able & Mean & Std. Dev. & $\mathrm{Mn}$ & Max & Observati ons \\
\hline $\begin{array}{c}\text { Imrew ov } \\
\text { bet } \\
\text { wi t }\end{array}$ & 7 & & $\begin{array}{r}1 \\
1 \\
-952.0115\end{array}$ & $\begin{array}{r}2024 \\
1103.189 \\
988.9885\end{array}$ & $\begin{aligned} \mathrm{N} & =47854 \\
\mathrm{n} & =1698 \\
\mathrm{~T}-\mathrm{bar} & =28.1826\end{aligned}$ \\
\hline $\begin{array}{l}y \text { ov } \\
\text { be } \\
\text { wi }\end{array}$ & 7 & & $\begin{array}{r}0 \\
0 \\
.1526863\end{array}$ & $\begin{array}{r}1 \\
1 \\
1.786953\end{array}$ & $\begin{aligned} N & =47854 \\
n & =1698 \\
T-b a r & =28.1826\end{aligned}$ \\
\hline $\begin{array}{l}\text { I h over } \\
\text { bet w } \\
\text { withi }\end{array}$ & 6 & & $\begin{array}{r}0 \\
0 \\
-230828.7\end{array}$ & $\begin{array}{r}791083 \\
257107.7 \\
539185.3\end{array}$ & $\begin{aligned} N & =47854 \\
n & =1698 \\
\text { T- bar } & =28.1826\end{aligned}$ \\
\hline $\begin{array}{r}\text { g_re-w ov } \\
\text { be } \\
\text { wi }\end{array}$ & 3. 919161 & & $\begin{array}{r}0 \\
1 \\
-.4819229\end{array}$ & $\begin{array}{r}5 \\
5 \\
7.155618\end{array}$ & $\begin{aligned} N & =47854 \\
n & =1698 \\
T-b a r & =28.1826\end{aligned}$ \\
\hline $\begin{array}{r}\text { r_rew ov } \\
\text { be } \\
\text { wi }\end{array}$ & 1.17 & & $\begin{array}{r}0 \\
0 \\
-1.453246\end{array}$ & $\begin{array}{r}5 \\
\text { 3. } 724745 \\
\text { 5. } 393639\end{array}$ & $\begin{aligned} \mathrm{N} & =47854 \\
\mathrm{n} & =1698 \\
\mathrm{~T}-\mathrm{bar} & =28.1826\end{aligned}$ \\
\hline $\begin{aligned} & \text { lotel__ } \sim \text { overal I } \\
& \text { bet ween } \\
& \text { wi thi n }\end{aligned}$ & 7 & & $\begin{array}{r}0 \\
0 \\
3.694007\end{array}$ & $\begin{array}{r}5 \\
5 \\
3.694007\end{array}$ & $\begin{aligned} \mathrm{N} & =47854 \\
\mathrm{n} & =1698 \\
\mathrm{~T}-\mathrm{bar} & =28.1826\end{aligned}$ \\
\hline W & 6 & $\begin{array}{r}268.9212 \\
262.703 \\
0\end{array}$ & $\begin{array}{r}30 \\
30 \\
370.4586\end{array}$ & $\begin{array}{r}1990 \\
1990 \\
370.4586\end{array}$ & $\begin{aligned} \mathrm{N} & =47854 \\
\mathrm{n} & =1698 \\
\mathrm{~T}-\text { bar } & =28.1826\end{aligned}$ \\
\hline
\end{tabular}

Figure 1 Summary Statistics.

This study compares random effect model and fixed effect model for panel data, and finds that fixed effect model is fit for the research model. Stata is used to do regression analysis for model (1), and $\ln \left(\right.$ price $\left._{i}\right)$ and hotel_class $i$ are deleted because of multicollinearity. The two control variables are deleted and model (1) and (2) are modified. The regression result of modified model (1) is as Figure 2. From the regression result, all independent variables are significant. And R-sq is 0.2830 which is normal.

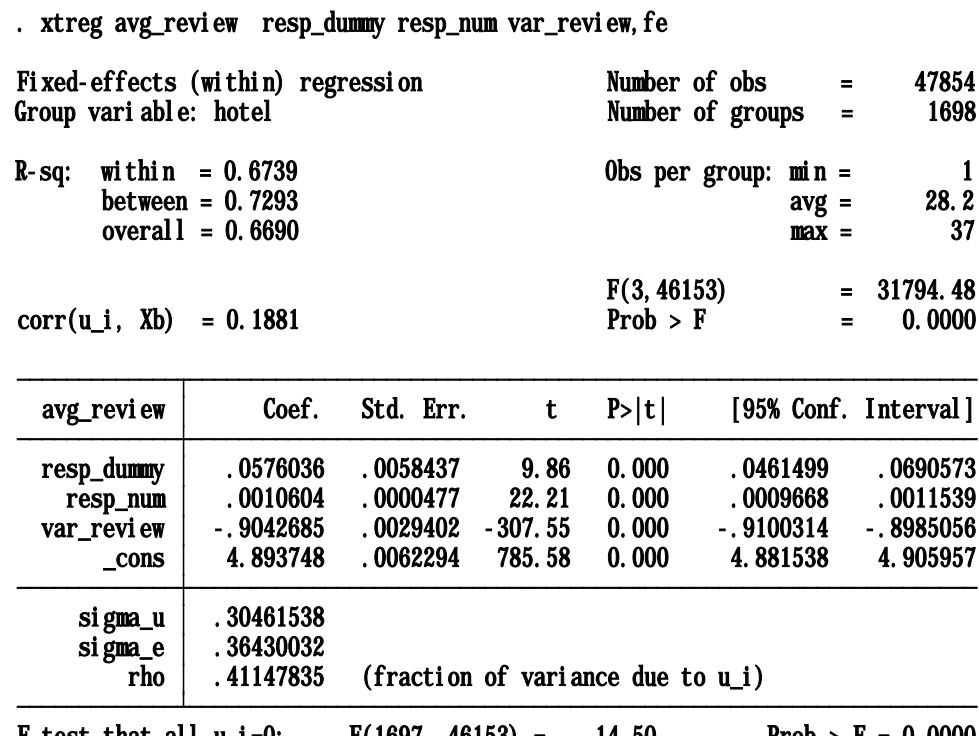

F test that al $u_{-} i=0: \quad F(1697,46153)=14.50 \quad$ Prob $>F=0.0000$

Figure 2 Regression result of model (1). 
The regression result of modified model (2) is as Figure 3. From the regression result, all independent variables are significant. And R-sq is 0.6690 which is normal.

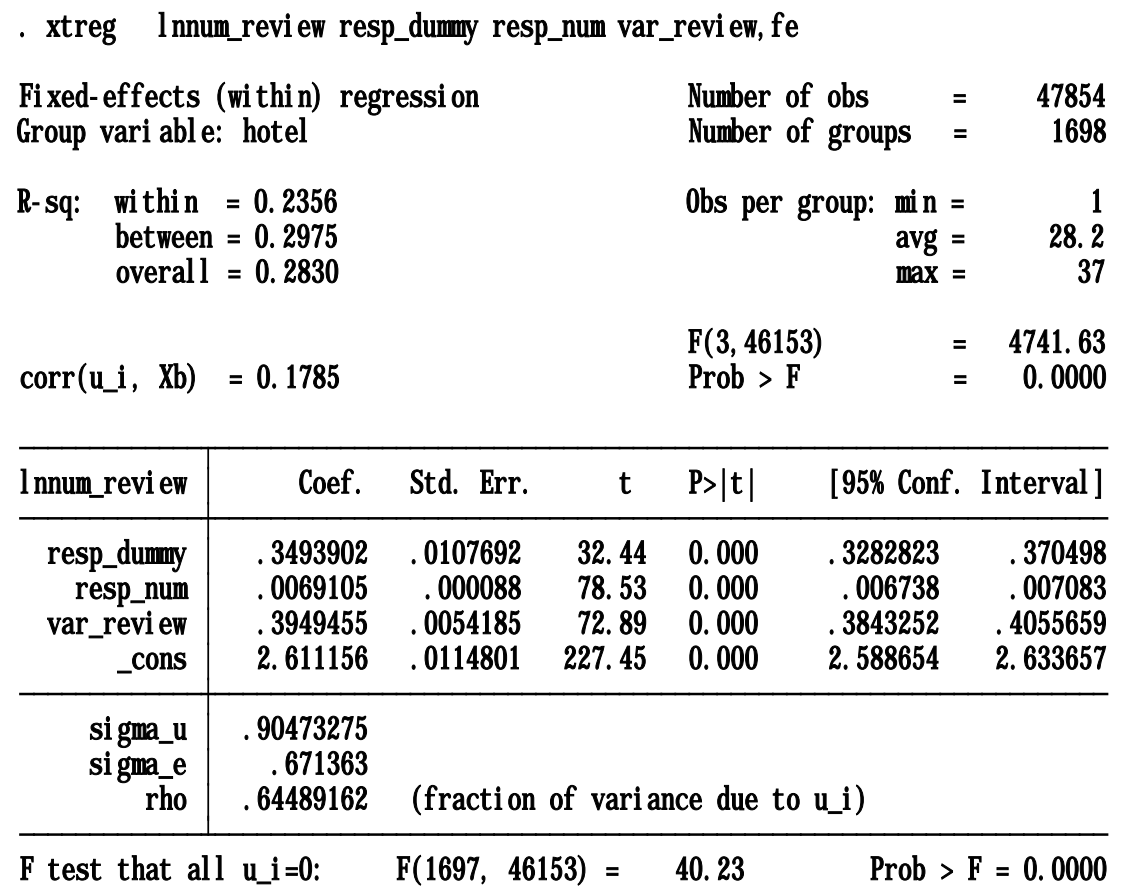

Figure 3 Regression result of model (2).

The two control variablesln $\left(\right.$ price $\left._{i}\right)$ and hotel_class ${ }_{i}$ are deleted, and model (3) and (4) are modified. The regression result of modified model (3) and (4) are as Figure 4 and Figure 5. From the regression results, all independent variables are significant. And R-sq are 0.3255 and 0.3625 respectively which are normal.

\begin{tabular}{|c|c|c|c|c|c|c|}
\hline \multicolumn{4}{|c|}{$\begin{array}{l}\text { Fi xed-effects (wi thi n) regressi on } \\
\text { Group vari able: hot el }\end{array}$} & \multicolumn{2}{|c|}{$\begin{array}{l}\text { Nunber of obs } \\
\text { Nunber of groups }\end{array}$} & $\begin{array}{l}3172 \\
1688\end{array}$ \\
\hline $\begin{array}{ll}\text { R-sq: } & \text { wi thin } \\
& \text { bet ween } \\
& \text { overal I }\end{array}$ & $\begin{array}{l}=0.5251 \\
=0.2034 \\
=0.3255\end{array}$ & & & Obs per & roup: $\begin{aligned} \min & = \\
\text { avg } & = \\
\max & =\end{aligned}$ & $\begin{array}{r}1 \\
1.9 \\
2\end{array}$ \\
\hline $\operatorname{corr}\left(u_{-} i, x b\right)$ & $=-0.4046$ & & & $\begin{array}{l}\mathrm{F}(3,1481 \\
\mathrm{PrOb}>\mathrm{F}\end{array}$ & & $\begin{array}{l}=545.84 \\
=\quad 0.0000\end{array}$ \\
\hline I nnum_r revi ew & Coef. & Std. Err. & $\mathrm{t}$ & $P>|t|$ & [ $95 \%$ Conf. & . Interval ] \\
\hline $\begin{array}{c}\text { resp_speed } \\
\text { resp_num } \\
\text { var_revi ew } \\
\text { _cons }\end{array}$ & $\begin{array}{l}1.571376 \\
.0176938 \\
.5025195 \\
.7136114\end{array}$ & $\begin{array}{r}.0707564 \\
.0007497 \\
.0436881 \\
.067029\end{array}$ & $\begin{array}{l}22.21 \\
23.60 \\
11.50 \\
10.65\end{array}$ & $\begin{array}{l}0.000 \\
0.000 \\
0.000 \\
0.000\end{array}$ & $\begin{array}{l}1.432582 \\
.0162233 \\
.4168225 \\
.5821296\end{array}$ & $\begin{array}{l}1.710169 \\
.0191643 \\
.5882166 \\
.8450933\end{array}$ \\
\hline $\begin{array}{l}\text { si gma_u } \\
\text { si gma e } \\
\text { rho }\end{array}$ & $\begin{array}{l}\text { 1. } 0193657 \\
1.0349421 \\
.49241814\end{array}$ & ( f raction & f varia & ce due to & u_i) & \\
\hline
\end{tabular}

Figure 4 Regression result of model (3). 


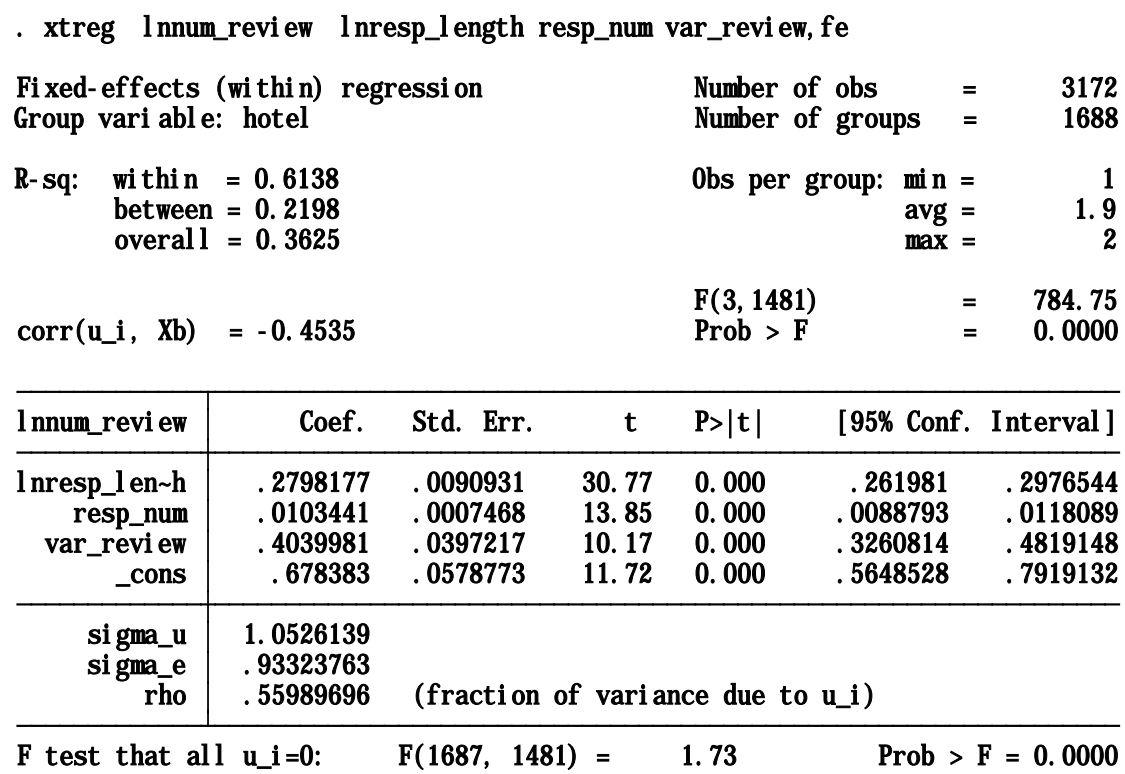

Figure 5 Regression result of model (4).

\subsection{Discussions}

For the result of model (1), the coefficient of resp_dummy $i t$ is 0.3493902 which is positive and highly significant. This indicates that non-monetary online service recovery has positive effect on firm performance. In other words, hotels that taking non-monetary online service recovery can have more online room sales than ones that not. This result supports H1a. The coefficient of resp_num which is positive and highly significant also verify this conclusion. The frequency of online hotels response to online customer reviews is positively correlated with online room sales.

For the result of model (2), the coefficient of resp_dummy $y_{i t}$ is 0.0576036 which is positive and significant. Considering variable values difference and highly significant result, this indicates that non-monetary online service recovery has positive effect on increasing customer perceived quality. This result supports H1b. The influence is small comparing with online room sales. From the regression result of _cons, it indicates that the fixed effect of hotels which refers to heterogeneous difference of hotels influence more on customer perceived quality.

For the result of model (3), the coefficient of resp_speed $d_{i t}$ is 1.571376 which is positive and highly significant. This indicates that the speed of non-monetary online service recovery positively affects firm sales. In other words, faster the speed of hotel non-monetary online response, higher the hotel room booking. This result supports H2.

For the result of model (4), the coefficient of resp_length ${ }_{i t}$ is 0.2798177 which is positive and highly significant. This indicates that the length of content of non-monetary online response positively affects firm sales. In other words, longer the content of hotels non-monetary online response, higher the hotel room booking sales. This result supports H3.

The coefficient of var_review $w_{i t}$ which is positive and highly significant on sales also verifies online customer review positively affect online hotel booking sales in prior studies. Findings suggest that all online customer reviews provide valuable reference for potential customers. Even for negative reviews, if hotels can provide online response in time, they still can increase sales. In the new features of Ctrip.com, there are two kinds of customer reviews: deserved recommendation and need to be improved. Negative reviews may be included in deserved recommendation. And positive reviews may indicate that the service need to be improved. It is difficult to distinguish positive reviews and negatives reviews precisely. This study includes the above two kinds of 
customer reviews, and find that both the average customer rating of hotels and rating variance provide rich information for future customers and positively affect online hotel room sales.

\section{Conclusions and Implications}

This study investigates the influence of online non-monetary service recovery on firm performance. Utilizing the independently developed network data crawler system based on HttpClient crawler assembly to capture the hotel information and customer reviews information and other related data of Ctrip.com, this study analyzes the panel data and test the model assumptions with the Stata model regression. The results reveal that non-monetary online service recovery has positive effect on online hotel bookings sales and increasing customer perceived quality, the speed and the length of content of non-monetary online response positively affects firm sales.

Results of this study have implications for theory as well as tourism practitioners, including hotels, restaurants, transportation and retail. This study has enriched tourism service marketing literature by examining the influence of online non-monetary service recovery on firm performance using procedural justice and interactional justice. Online reviews provide opportunity to contact each other for customers and online service website, so effective management of online reviews is particularly important. Firms can provide responses to customer reviews to improve their service quality and sales. Online service firm should take non-monetary online service recovery quickly an in time. This study suggests that taking online service recovery in time and quickly is an effective method to increase customer perceived fairness and firm sales. When online service firms take online non-monetary service recovery, they should show courteous and sincerity. The response frequency and content length can reveal courteous and sincerity of firm service recovery, then increase customer interactional fairness and firm sales.

This study also has some limitations. For example, online hotel booking platforms do not publish hotel sales. This research only select quantity variables such as response speed and content length to analyze the influence of hotel service recovery on firm performance. There are many variables impact on customer purchase decision that cannot be included in this research model. Future research will conduct response content analysis and assess how the content of online service recovery influences firm performance.

\section{References}

[1] A.B. del Río-Lanza, R. Vázquez-Casielles, and A.M. Díaz-Martín, J., 2013. Satisfaction with service recovery: Perceived justice and emotional responses, Journal of Business Research. 62, pp. 775-781.

[2] A.K. Smith, R.N. Bolton, and J.Wagner, J., 1999. A model of customer satisfaction with services encounters involving failure and recovery, Journal of Marketing Research. 36, pp. 356-72.

[3] B. Gu, Q. Ye, J., 2010. The Impact of Online Service Recovery on Customer Satisfaction: Empirical Evidences from Service Operations in China, McCombs Research Paper Series. No. IROM-01-10.

[4] B.C. Wen, C. Chi, J., 2013. Examine the cognitive and affective antecedents to service recovery satisfaction: A field study of delayed airline passengers, International Journal of Contemporary Hospitality Management. pp. $306-327$.

[5] C. Boshoff, J., 1997. An empirical examination of service recovery design, International Journal of Service Industry Management. Vol. 8, Iss. 2, pp. 110-130.

[6] C. Boshoff, J., 2012. Can Service Firms Overdo Service Recovery? An Assessment of Non-Linearity in Service Recovery Satisfaction, South African Journal of Business Management. 43(3), pp. 1-12.

[7] C.M.K. Cheung, N. Lee, and K.O. Matthew, J., 2012. What Drives Consumers to Spread Electronic Word of Mouth in Online Consumer - opinion Platforms, Decision Support Systems. 53(1), pp. 218-222.

[8] C. Gronroos, J., 1988. Service Quality: The Six Criteria of Good Perceived Service Quality, Review of Business. 9 (Winter), pp. 10-13.

[9] D. Proserpio, G. Zervas, J., 2017. Online Reputation Management: Estimating the Impact of Management Responses on Consumer Reviews, Marketing Science. 36(5), pp. 645-655. 
[10] G. Priyanga, H.X. Rui, and S. Avi, J., 2014. Customer Service on Social Media: The Effect of Customer Popularity and Sentiment on Airline Response. 35th International Conference on Information Systems, Auckland 2014 (ICIS 2014), Auckland. pp. 1-20.

[11] G. Yin, Q. Zhang, \& Y. Li, J., 2014. Effects of Emotional Valence and Arousal on Consumer Perceptions of Online Review Helpfulness, The 20th Americas Conference on Information Systems.

[12] J.A, Chevalier, D. Mayzlin, J., 2006. The Effect of Word of Mouth on Sales: Online Book Reviews, Journal of Marketing Research. 43(3), pp. 345-354.

[13] J. Cui, Y. Pan, and L. Wang, J., 2012. Impact of Online Review on Sales: An Empirical Investigation of Experience Products with Different Popularities, 2012 International Conference on Management of e-Commerce and eGovernment.

[14] J. Cui, L. Wang, H. Feng, and Y. Teng, J., 2014. Empirical Study of the Motivations of E-WOM Spreading on Online Feedback System in China, Pacific Asia Conference on Information Systems 2014.

[15] J.G. Maxham, J., 2001. Service recovery's influence on consumer satisfaction, positive word-of-mouth, and purchase intentions, Journal of Business Research. 54(1), pp. 11-24.

[16] J. Singh, B. Crisafulli, J., 2016. Managing Online Service Recovery: Procedures, Justice and Customer Satisfaction, Journal of Service Theory and Practice. 26(6), pp. 764-787.

[17] J. Wael, Z.Q. Zheng, J., 2014. Know Yourself and Know Your Enemy: An Analysis of Firm Recommendations And Consumer Reviews In A Competitive Environment, MIS Quarterly. 38(3), pp. 635-654.

[18] J. Wirtz, J.R. McColl-kennedy, J., 2010. Opportunistic Customer Claiming During Service Recovery, Journal of the Academic Marketing Science. 38(5), pp. 654-675.

[19] M.A. Hocutt, G. Chakraborty, J.C. Mowen, J., 1997. The Impact of Perceived Justice on Customer Satisfaction and Intention to Complain in a Service Recovery, Advances in Consumer Research. 24(1), pp. 457-463.

[20] M. Pinto, and P. Mansfield, J., 2011. Facebook as a complaint mechanism: An investigation of millennials, Journal of Behavioural Studies in Business. 4, pp. 1-12.

[21] M. Steven, J., 2015. Let Justice be Done, From Coach to First Class: Examining Service Recovery Through Justice Theory, Tourism Travel and Research Association: Advancing Tourism Research Globally.

[22] Q. Li, J. Cui, and Y. Gao, J., 2015. The Influence of Social Capital in an Online Community on Online Review Quality in China, 48th Hawaii International Conference on System Sciences. pp. 562-570.

[23] Q.H. Li, H.T. Chuan, L.K. Wei, and K.W. Kwok, J., 2014. Comprehension and Assessment of Product Reviews: A Review-Product Congruity Proposition, Journal of Management Information Systems. 30(3), pp. 311-343.

[24] Q. Ye, B. Gu, J., 2014. First Step in Social Media: Measuring the Influence of Online Management Responses on Customer Satisfaction, Production and Operations Management. 23(4), pp. 570-582,

[25] Q. Ye, R. Law, and B. Gu, J., 2009. The impact of online user reviews on hotel room sales, International Journal of Hospitality Management. 28(1), pp. 180-182.

[26] S.W. Huang, Y.W. Hung, T.W. Fu, J.S.C Hsu, and C.M. Chiu, J., 2015. Understanding the Impact of Service Failure and Recovery Justice on Consumers' Satisfaction and Repurchase Intention, Pacific Asia Conference on Information Systems 2015.

[27] S. Rasoulian, Y. Grégoire, R. Legoux, \& S. Sénécal, J., 2017. Service Crisis Recovery and Firm Performance: Insights from Information Bbreach Announcements, Journal of the Academy Marketing Science.

[28] S. Swanson, \& M. Hsu, J., 2011.The Effect of Recovery Locus Attributions and Service Failure Severity on Wordof- Mouth and Repurchase Behaviors in the Hospitality Industry, Journal of Hospitality \& Tourism Research. 35 (4), 511-29.

[29] S. Yang, M. Hu, S.W. Russell, H. Assael, and X.H. Chen, J., 2012. An Empirical Study of Word-of-Mouth Generation and Consumption, Marketing Science. 31, pp. 952-963.

[30] W. Mangold, and K. Smith, J., 2012. Selling to millennials with online reviews, Business Horizons., 55(2), pp. 141153. 